\title{
How inclusive education is understood by principals of independent schools
}

by

\section{Jennifer Gous}

\section{Submitted in partial fulfillment of the requirements for the degree}

\section{Philosophiae Doctor}

\author{
at the \\ Department of Education Management and Policy Studies \\ Faculty of Education \\ University of Pretoria
}

Supervisor:

Professor Dr Irma Eloff

PRETORIA

2009

(C) University of Pretoria 
For my mother and father

Catherine and Monty Gous and my aunt

Des Oldfield 
By focusing on the ruins of history and the fragmentation of agreed upon meaning, we move against a victory narrative couched in the very conquering optimism that has lost its credibility, and toward some sense of what it means to use the now-time of a crisis of otherness to struggle toward a more just society. 


\section{Acknowledgements}

A thesis might be one's own work with many hours spent at a desk but without the support and encouragement of those around one, the task would be that much more difficult. For this reason I wish to say a heartfelt and warm thank you to the following people for supporting me through this process. To the following:

- My friends, family and colleagues who have supported me throughout the writing of this thesis. Their continuous interest in my research has been an indication of their care and love for me. being generous in granting me study leave when I needed it most.

The friends who proofread sections of my thesis to make sure that it was coherent and comprehensible - Liz Spann, Heather Drage and Jane Bird.

- My supervisor Prof Irma Eloff, a truly sanctified 'mensch' whose depth of wisdom, welcoming spirit, refreshing sense of humour, deep academic insight, valued guidance, and gracious support sustained me through the years of writing this thesis. I could not have wished for a better mentor.

Professor Juan Bornman and Dr Suzanne Bester for being the critical readers of my proposal.

- Professor Jonathan Jansen, Dr Chaya Herman and Dr Venitha Pillay who gave me the opportunity to study as a PhD student at the University of Pretoria.

- The librarians and especially Clarisse Venter at the University of Pretoria who gave me endlessly efficient and willing help with sourcing materials, articles, books and journals.

- The Oppenheimer Memorial Trust for their generous grant of R50 000 to make this study possible.

- My kitty Muffin who kept me company at my desk for many hours and who occasionally made her own contribution by walking across my keyboard.

- Liz who accommodated my days in my study and who developed and illustrated the quilt design for my major findings.

- Jane who gave me insight into quilts.

○ Adrie van Dyk for being my expert technical reader and thesis 'designer'.

○ The Rabbi with whom I had an enlightening conversation on community. 
○ The informal discussion I had with Dr Melody Hougaard regarding the inclusive process in South Africa.

- My examiners who gave me unexpected and caring support in their thoughtful analyses and comments.

- My participants whose knowledge and experiences were readily and generously shared with me. This study would not have been possible without their input and I am deeply grateful to them for being willing participants and co-authors.

- To the One who has been beside me throughout the process, who took me to depths where I found the unsearchable and where I learnt a little more about who I am, I thank you. 


\section{Declaration}

I declare that the thesis which I hereby submit for the degree Philosophiae Doctor in

Education Policy and Management Studies at the University of Pretoria, is my own work and has not previously been submitted by me for a degree at this or any other tertiary institution

Jennifer Gous

Signed on the day of 2010 Johannesburg South Africa 
In recognition that every child matters, inclusive education has become a practice that has been adopted by many schools across the globe and most usually in first world countries. As a whole-school system it occurs less frequently in developing countries including South Africa which, unlike many developing countries, has a sound infrastructure and many excellent schools in both the state and the independent sectors. 'Education White Paper 6: Special education: Building an inclusive education and training system' was published in 2001 with the express intention of developing an inclusive education system in South Africa. Some independent schools have successfully implemented exemplary forms of inclusion in their schools and this is the phenomenon that has been studied by focusing on the understandings and experiences of the principals. As the researcher I interviewed eight principals who are practicing inclusive education as the norm in their schools. This study reveals various aspects of the inclusive process including the pivotal role that principals play in the transformation process of which inclusive education is the harbinger. It also analyses why principals choose to embrace a paradigm that on the surface is uncomfortable and not an easy option. I used biographical narrative research as methodology for this qualitative research and crystallisation as quality strategy in order to study the phenomenon that is the understandings of principals of independent schools of inclusive education. The basic tenet was that inclusion leads to belonging and excellence in education. The major findings and implications for action are of interest not only to principals, but to anyone who is seriously interested in innovative and more humane forms of anti-oppressive education. 


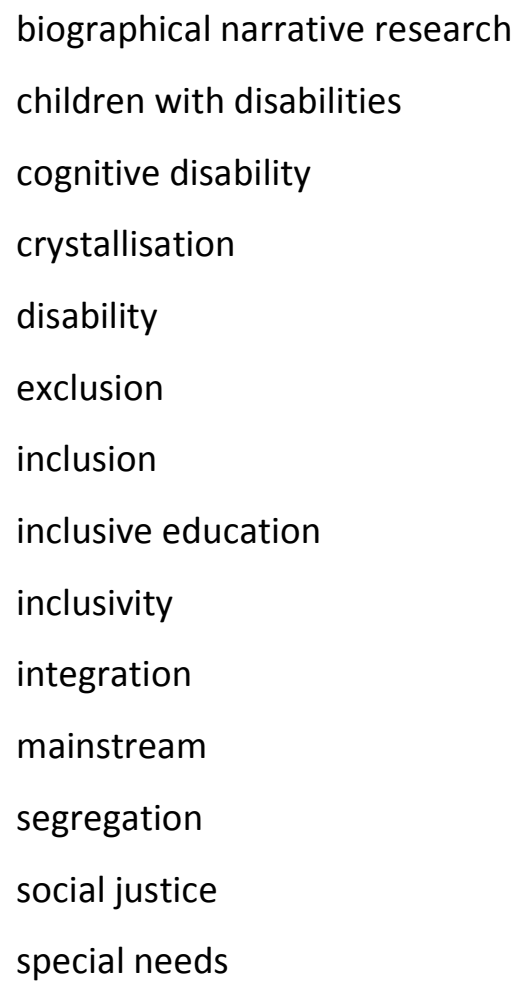

attitudes

disability

exclusion

feminism

gender

hidden

inclusion

inclusive education

independent schools

leadership marginalisation

othering

perceptions

principals

queer theory

science

silence

special needs

special schools

voice 
ASD $\quad$ Autistic Spectrum Disorders

CAAC Centre for Alternative and Augmentative Communication, University of Pretoria

DoE Department of Education

ECD Early Childhood Development

EFA Education for All

EWP6 Education White Paper 6 on Special Needs Education: Building an Inclusive Education and Training System

FET Further Education and Training

GETC General Education Training Certificate

IE Inclusive Education

IEP Individual Education Plan/Programme

ISASA Independent Schools Association of South Africa

MVA Motor Vehicle Accident

SAALED South African Association for Learning and Educational Difficulties

SENCO Special Educational Needs Coordinator

TEFL Teaching English as a Foreign Language

WP6 Education White Paper 6 on Special Needs Education: Building an Inclusive Education and Training System 
Abstract

Key terms

Words used singly or in combination in electronic searches ii

Acronyms

Chapter 1

Introduction and orientation

$1.1 \quad$ INTRODUCTION TO THE STUDY 1

1.2 INTRODUCTION TO THE RESEARCH PROBLEM AND PURPOSE

1.3 GENERAL AREA UNDER STUDY 5

$1.4 \quad$ PROBLEM STATEMENT 6

$1.5 \quad M Y$ SPECIFIC STUDY 8

1.6 PURPOSE OF THE STUDY 8

1.7 WHY INCLUSIVE EDUCATION?

$1.8 \quad$ WHY THE FOCUS ON PRINCIPALS?

1.9 WHY THE FOCUS ON INDEPENDENT SCHOOLS?

$1.10 \quad$ INCLUSIVE EDUCATION IN INDEPENDENT SCHOOLS

1.11 HOW I CAME TO DO THIS STUDY?

1.12 PURPOSE STATEMENT

1.13 RESEARCH QUESTIONS 21

1.14 CONCLUSION

$$
\text { ---OOO--- }
$$




\section{Chapter 2}

The literature review

$2.1 \quad$ INTRODUCTION

2.2 THE CHALLENGE OF INCLUSIVE EDUCATION

2.3 TYPES OF INCLUSION

2.4 INTERROGATING THE KNOWLEDGE BASE ON INCLUSIVE EDUCATION

2.4.1 DEFINITION OF INCLUSIVE EDUCATION

2.4.2 INCLUSION AS A BROADER SOCIAL ISSUE

$\begin{array}{ll}2.4 .3 & \text { LOCATION OF THE PROBLEM }\end{array}$

2.4.4 IDENTITY AND LEARNING

2.4.5 Problematising NORMaLISATION AND DEVIATION 43

2.4.6 VOICES FALLING ON DEAF EARS

2.4.7 EXPLORING OTHERNESS

2.4.8 PRINCIPALS AS AGENTS OF CHANGE

2.4.9 THE BIAS OF THE EDUCATIONAL CHANGE LITERATURE 53

2.4.10 FEMINIST RESEARCH 54

2.5 SUMMARISING THE LITERATURE ON INCLUSIVE EDUCATION 57 


\section{Chapter 3}

Explaining the methodology

3.1 INTRODUCTION

$3.2 \quad$ CONCEPTUAL FRAMEWORK 58

3.3 RESEARCH DESIGN 62

3.3.1 RESEARCH AIM 62

3.3.2 RESEARCH PARADIGM 62

3.3.3 RESEARCH METHODOLOGY

3.3.4 DATA COLLECTION METHODS 68

3.3.5 INDIVIDUAL INTERVIEWS 69

3.3.6 DIRECT OBSERVATION 71

3.3.7 TAKING FIELD NOTES 71

3.3.8 DOCUMENT ANALYSIS 72

3.3.9 APPROACH TO COLLECTION OF DATA 72

3.3.10 BRINGING THE DATA SOURCES TOGETHER 73

3.3.11 RESEARCH DIARY 73

3.3.12 DATA ANALYSIS 74

3.3.13 VALIDATION STRATEGIES 75

3.3.13.1 Crystallisation $\quad 75$

3.3.13.2 Participant validation 76

3.3.13.3 Peer review 76

3.3.13.4 Rich (thick) description 76

3.3.13.5 Interpretive explanation 77

3.3.14 LIMITATIONS OF THE STUDY 77

3.3.15 STRENGTHS OF THE STUDY 78

3.3.16 ETHICAL CONSIDERATIONS 78 


\section{Chapter 4}

Presenting the data

4.1 INTRODUCTION

4.2 THE PARTICIPANTS 80

4.2.1 DEMOGRAPHIC DESCRIPTION OF PARTICIPANTS 81

4.2.2 THE SETTINGS 83

4.3 EMBRACING AN ARTISTIC GENRE 86

4.4 HOW IT ALL BEGAN... 88

4.5 TYPES OF DISABILITIES ACCOMMODATED IN SCHOOLS

4.6 MAJOR FINDINGS AS DERIVED FROM THE THEMES

4.6.1 INCLUSION IS PERSONAL $\quad 93$

4.6.2 IT'S ABOUT TAKING ACTION 110

4.6.3 IT'S PRAGMATIC 122

4.6.4 IT'S ABOUT OUR HUMANITY 163

4.6.5 IT'S ABOUT EMOTION

$\begin{array}{ll}4.7 & \text { CAVEATS TO INCLUSION } \\ & 187\end{array}$

$\begin{array}{lll}\text { 4.7.1 GOVERNMENT INVOLVEMENT } & 187\end{array}$

4.7.2 TIMING 188

4.7.3 HARD WORK AND EFFORT 190

4.7.4 FUNDING ISSUES 191 


\section{Chapter 5}

Overview, Findings and Recommendations

$5.1 \quad$ INTRODUCTION

5.2 SUMMARY OF THE STUDY

5.3 OVERVIEW OF THE PROBLEM

200

5.3 .1

PURPOSE STATEMENT AND RESEARCH QUESTIONS

200

5.3 .2

REVIEW OF THE METHODOLOGY

201

5.3.3 CONCEPTUAL FRAMEWORK

$5.4 \quad$ FINDINGS RELATED TO THE LITERATURE

5.4.1 POLICY 211

5.4.2 TYPES OF INCLUSION PRACTICED

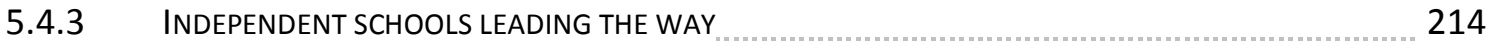

5.4.4 RESTRUCTURING A SCHOOL SYSTEM

5.4.5 CHECKING WEBSITES AGAINST THE DATA

$5.5 \quad$ SURPRISES 227

$5.6 \quad$ CONCLUSIONS 232

5.6.1 IMPLICATIONS FOR ACTION 232

5.6.2 RECOMMENDATIONS FOR FURTHER RESEARCH 233

5.7 CONCLUDING REMARKS 233

Endnotes 236

References 238

Additional References 253 


\section{List of Graphics}

Graphic 1 Traditional teaching method 32

Graphic 2 Accelerated learning as a result of a sense of belonging 32

\section{List of Figures}

Figure 1 Matrix One: Curricular and assessment specifications 59

Figure 2 Matrix Two: Curricular expectations 60

Figure 3 Matrix Three 61

\section{List of Tables, Map and Diagram}

Table $1 \quad$ Personal details of participants 82

Table 2 Length of interviews 85

Table 3 How the concept of inclusive education is defined by the principals _......... 88

Table 4 Types of disabilities and amount of support needed in the schools 91

Table 5 Details regarding number of paid support staff

Table 6 Types of adaptations

Table 7 Degree of inclusion taking place in each school

Table 8 Types of inclusion (as harvested from the literature) being practiced

Map 1 The Provinces of South Africa 
APPENDIX A

Excerpts from the Salamanca and Dakar Statements

260

APPENDIX B

Maslow's 'hierarchy of needs'

261

APPENDIX C

Excerpt from White Paper 6

APPENDIX D

How the interview questions were formulated

APPENDIXE

Excerpt from research diary

APPENDIX F

Ethical clearance certificate

APPENDIX G

Round Square Schools

APPENDIX H

The Klingenstein Centre

APPENDIX I

Excerpts from websites 